\title{
Regulation of GAD expression in rat pancreatic islets and brain by $\gamma$-vinyl-GABA and glucose
}

\author{
J.S.Petersen ${ }^{1}$, K. Rimvall ${ }^{2}$, P.N.Jørgensen ${ }^{3}$, E.Hasselager ${ }^{4}$, A. Moody ${ }^{4}$, K.Hejnæs ${ }^{4}$, J. T. Clausen ${ }^{4}$, T. Dyrberg ${ }^{4}$ \\ ${ }^{1}$ Hagedorn Research Institute, Gentofte, Denmark \\ ${ }^{2}$ Novo Nordisk A/S, Måløv, Denmark \\ ${ }^{3}$ Novo Nordisk A/S, Science Park Symbion, Copenhagen, Denmark \\ ${ }^{4}$ Novo Nordisk A/S, Bagsværd, Denmark
}

\begin{abstract}
Summary Glutamic acid decarboxylase (GAD) is an important autoantigen in insulin-dependent diabetes mellitus (IDDM), but little is known about its regulation and function in islet cells. We investigated the effects of the GABA-transaminase inhibitor $\gamma$-vinylGABA (GVG) on GAD expression in rat islets and brain in vitro and in vivo. In islets incubated in high glucose culture medium there was an increase in GAD activity, GAD65 and GAD67 protein levels compared to low-glucose conditions; however, even in high glucose, GVG still significantly suppressed GAD activity and GAD67 expression. Our observations suggest that glucose and GVG act on GAD in islets through different mechanisms. Quantitative immunohistochemistry of pancreatic sections from rats treated with GVG in vivo using novel monoclonal antibodies specific for GAD65 and GAD67, showed a decrease in GAD67 expression $(p<0.005)$ relative to untreated rats. The effects of GVG on rat pancrea-
\end{abstract}

tic islets were very similar to those observed in brain of rats treated with GVG in vivo. In homogenates of cerebral tissue from $\mathrm{GVG}$ treated rats containing both membrane-bound and soluble protein GAD67 levels were significantly decreased while GAD65 levels were not significantly changed compared to untreated rats. In contrast, in homogenates of cerebral tissues containing only soluble cytosolic protein, GVG-treatment was also significantly found to decrease GAD65 levels. Taken together, these results suggest that GVG potentially could be of use to decrease GAD expression in islet cells and consequently to deviate/inhibit the autoimmune response against the beta cells seen in IDDM. [Diabetologia (1998) 41: 530-535]

Keywords GAD, GABA, GABA-transaminase, GVG, pancreas, brain, rat, islet
Glutamate decarboxylase (GAD;EC4.1.1.15) exists as twoisozymes, GAD67 and GAD65, which are encoded by two separate genes [1], have different biochemical characteristics and are differentially regulated and distributed in nerve cells in the central nervous system

Received: 19 August 1997

and in final revised form: 22 December 1997

Corresponding author: Dr. T.Dyrberg, Novo Nordisk A/S, DK-2880 Bagsværd, Denmark

Abbreviations: GAD, Glutamic acid decarboxylase; GABA, $\gamma$ aminobutyric acid; GVG, $\gamma$-vinyl-GABA; CNS, central nervous system; IDDM, insulin-dependent diabetes mellitus; SDS, sodium dodecyl sulphate; mAbs, monoclonal antibodies; NSE, neuron-specific enolase; BHK, baby hamster kidney.
(CNS) (see [2] for review). In rat, GAD65 and GAD67 are both expressed in the insulin-producing beta cell of the pancreatic islets. In contrast, in man, GAD65 is found in all islet cells whereas GAD67 expression cannot be detected at all [3] or only at very low levels [4]. GAD is a major autoantigen in the pathogenesis of insulin-dependent diabetes mellitus (IDDM) and of a rare, neurological disorder, stiff-man syndrome, which is often associated with diabetes [5, 6]. Autoanibodies [7] and T-cell reactivity [8] against GAD65 can be detected in the majority of recent onset IDDM patients as well as several years before clinical onset of the disease. However, relatively little is known about the regulation of GAD expression in pancreatic islets and even less is known about the physiological or pathophysiological function of GAD in these cells. 
In the CNS of mammals, both GAD65 and GAD67 are widely expressed in neurons and responsible for the synthesis of the important inhibitory neurotransmitter $\gamma$-aminobutyric acid (GABA). It has been demonstrated that GAD expression in brain and cultured neurons can be manipulated using the GABA-transaminase inhibitor $\gamma$-vinyl-GABA (GVG). Administration of this drug leads to substantial decreases in GAD enzymatic activity and GAD67 levels, while the levels of GAD65 remain largely unchanged $[9,10]$. GVG is used clinically in the treatment of certain types of epilepsy and there is one report showing its usefulness in the treatment of stiff-man syndrome [11].

The current study was initiated in order to investigate the regulative properties of GAD expression in islets. We wanted to determine whether GVG had the same effects on GAD expression in rat pancreatic beta cells as it does in rat nerve cells and to analyse the effects of varying glucose levels on GAD65 and GAD67 expression in islets in the presence and absence of GVG. Using a combination of several biochemical, enzymological and morphological techniques, we report that GVG has very similar effects on GAD expression in brain and in pancreatic islets, in vivo as well as in vitro, and that glucose and GVG act on GAD in islets through different mechanisms.

\section{Materials and methods}

Antibodies. The rabbit antiserum R1266 recognizes GAD67 and GAD65 equally well [12]. The neuron-specific enolase (NSE) antiserum was obtained from Incstar (Stillwater, Minn., USA). These two antisera were used for the immunoblotting studies.

The GAD65 and GAD67 monoclonal antibodies (mAbs), named EJ65 and EJ67 respectively, were produced by immunizing RBF mice [13] with purified recombinant human islet GAD65 [14] or partially purified rat islet GAD67 (Moody et al., unpublished). Over a period of 2 months each animal received three subcutaneous injections of antigen in Freunds adjuvant (the first complete, the last two incomplete). Mice with high levels of GAD antibodies, as tested in a radioligand assay [15], were boosted by an i.v. injection of antigen in saline 4 days before their spleen cells were fused with FOX-NY myeloma cells [13]. The cells were screened for production of specific antibodies 17 days later. Two hybridomas, producing specific antibodies against GAD65 (IgG26) and GAD67 (IgG1) respectively, were selected and recloned once, a batch of antibody was produced from each hybridoma and the cells were stored in aliquots at $-140^{\circ} \mathrm{C}$. Details of their specificities are given below (Fig. 1). These mAbs were used for immunocytochemical staining of pancreatic sections.

Animals. Male, adult Wistar rats (approximately $200 \mathrm{~g}$ ), with free access to food in order to maintain a normal blood glucose, received either GVG (Vigabatrin, Astra, Södertälje, Sweden; $150 \mathrm{mg} / \mathrm{kg}$ ) or $154 \mathrm{mmol} / \mathrm{l} \mathrm{NaCl}$ by subcutaneous injections daily for 3 days. This treatment regimen has previously been shown to induce maximal changes in GAD expression [10]. $24 \mathrm{~h}$ after the last injection the animals were killed, the brains and the pancreata were removed and immediately frozen on ethanol/dry ice. The procedure adhered to current animal care guidelines.

Cell preparations. In three separate experiments islets were isolated from groups of eight adult Wistar rats by collagenase digestion [16]. Each of the three batches of purified islets were divided into four aliquots (1600-1900 islets per aliquot) and cultured for $24 \mathrm{~h}$ in RPMI 1640 with $5 \%$ fetal calf serum, 5 or $20 \mathrm{mmol} / \mathrm{l}$ glucose and with or without GVG $(1 \mathrm{mg} / \mathrm{ml})$. Thereafter, the islets were washed 3 times in PBS by centrifugation, homogenized and centrifuged at $100000 \times \mathrm{g}$ for $1 \mathrm{~h}$ at $4{ }^{\circ} \mathrm{C}$. Thus, islet cell preparations containing soluble, cytosolic proteins, i.e. "soluble-protein fractions", were obtained [3]. These preparations were stored at $-80^{\circ} \mathrm{C}$ until analysis of GAD activity and GAD protein levels. Preliminary experiments had demonstrated that GVG $1 \mathrm{mg} / \mathrm{ml}$ was not toxic to islet cells as evidenced by visual inspection, protein analysis and quantitative immunoblot analysis of marker proteins.

Cerebrum, i.e., the whole brain except the cerebellum and cerebellum were dissected from the brains of adult Wistar rats that had been injected either with GVG or buffer (see above). The brain tissues were incubated on ice for $10 \mathrm{~min}$ in a HLB buffer $\left(10 \mathrm{mmol} / \mathrm{l} \mathrm{HEPES}\right.$, pH 7.4, with $1 \mathrm{mmol} / \mathrm{l} \mathrm{MgCl}_{2}$ and $1 \mathrm{mmol} / \mathrm{l}$ EGTA) and thereafter homogenized. These homogenates were either used directly as "total-protein fractions" containing both membrane-associated and soluble, cytosolic proteins, or further processed, as described above for isolated islets, to obtain preparations with only soluble, cytosolic proteins, i. e. "soluble-protein fractions".

$G A D$ activity. The enzymatic activity of GAD was assayed as previously described $[14,17]$ by measuring the conversion of L- $\left(1-{ }^{14} \mathrm{C}\right)$ glutamic acid (Amersham Amersham, UK) to ${ }^{14} \mathrm{CO}_{2}$. One enzyme unit is defined as $1 \mu \mathrm{mol}$ of product formed per minute at $37^{\circ} \mathrm{C}$. The actual level of GAD enzyme activity for islets incubated in $5 \mathrm{mmol} / \mathrm{l}$ glucose was found to be $18-22 \mu \mathrm{U} /$ islet equivalent in accordance with previous reports.

Immunoblotting analysis. Tissue samples were boiled for $10 \mathrm{~min}$ in $1 \mathrm{~mol} / \mathrm{l}$ Tris, $60 \%(\mathrm{v} / \mathrm{v})$ sucrose, $15 \%(\mathrm{w} / \mathrm{v})$ sodium dodecyl sulphate (SDS), $0.01 \%$ (w/v) bromophenol blue, pH 6.8, with $1 \%$ b-mercaptoethanol and subjected to SDSpolyacrylamide gel electrophoresis. The gels were electroblotted onto Immobilon membranes (Millipore, Bedford, Mass., USA), and the blots were blocked by incubation for $1 \mathrm{~h}$ in $0.1 \%$ Tween- 20 and $3 \%$ skim milk. Blots were incubated for $1.5 \mathrm{~h}$ with the primary antiserum (R1266 1:500, NSE 1:500) in TBST containing 3\% skim milk. Subsequently, the blots were incubated with ${ }^{35} \mathrm{~S}$-methionine-labelled goat-antirabbit $\operatorname{Ig}(\mathrm{H}+\mathrm{L})$ (Amersham) and goat-anti mouse $\mathrm{Ig}(\mathrm{H}+\mathrm{L})$ (Amersham). The staining intensities of the GAD65, the GAD67 and, in the case of brain samples, the NSE bands were quantified in each lane on a Phosphor Imager (Molecular Dynamics, Sunnyvale, Cal., USA). In order to minimize interand intra-assay variability, GAD staining intensities were expressed relative to NSE staining intensity in the same electrophoretic lanes [18]. Staining intensities were linear within the analysed range (not shown). For islets the relative amount of GAD65 and GAD67 staining were not quantified relative to a household protein like NSE, but to a similar number of islet/protein. The variability of this method was less than $13 \%$.

$G A D$ immunocytochemistry. Immunocytochemical analysis was performed on cryostat sections of pancreata from four sal- 


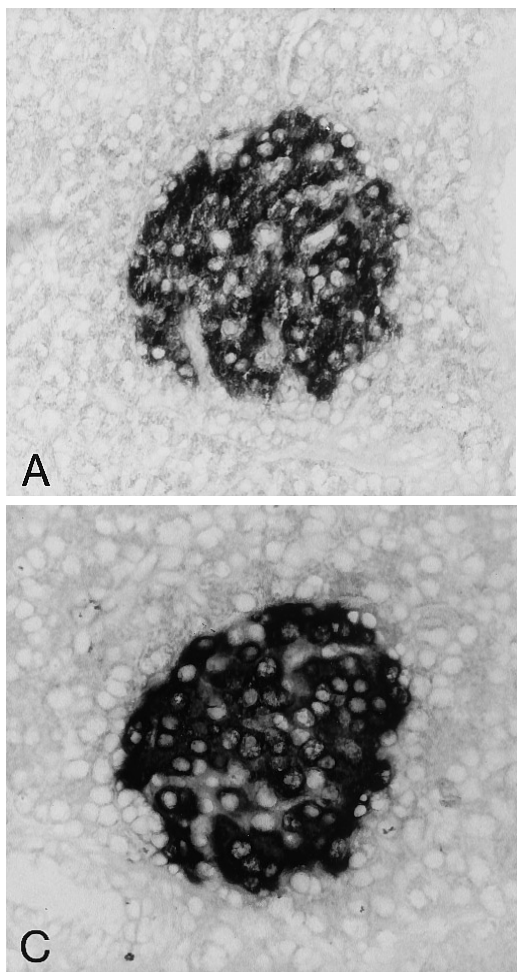

Fig. 1. A-D Effects of in vivo GVG treatment on rat islet GAD protein content: immunocytochemistry. Histological sections of pancreata of rats treated in vivo with GVG were compared with sections from saline-treated rats at identical magnification. Two-layer indirect immunohistochemical methods for GAD staining (see Materials and methods) give a positive reaction in beta cells of pancreatic islets. Bar $=30 \mu \mathrm{m}$. A. Saline-treated rat. Immunohistochemical reaction for GAD67 is seen as intense, cytoplasmic granules in beta cells. B. GVG-treated rat. GAD67 reaction is reduced in beta-cell cytoplasm and now are seen as separated grey granules. Only a few beta cells with intense staining are observed (arrow). C. Saline-treated rat. GAD65 reaction is intense and confluent in beta-cell cytoplasm. D. GVG-treated rat. GAD65 reaction intensity is slightly reduced and granular in beta cells

ine-treated and four GVG-treated rats using the mAbs specific for GAD65 and GAD67 (see above) and a biotinylated sheepanti-mouse g-globulin as secondary antibody. A streptavidin alkaline phosphatase conjugate served as a detection system with Nitro Blue Tetrazolium/Bromo-Chloro-Indolyl-Phosphate as substrate. The reaction products appeared as a blue/ black staining. The digitized images of endocrine pancreata were obtained by video-assisted bright field microscopy and analysed. Five different areas within the endocrine pancreas of each of the eight rats were digitized, GAD positive cells were selected by thresholding and the mean optical densities in each of these five areas were calculated for all eight animals. The mean optical density of exocrine pancreas in five areas in each rat was subtracted as background.

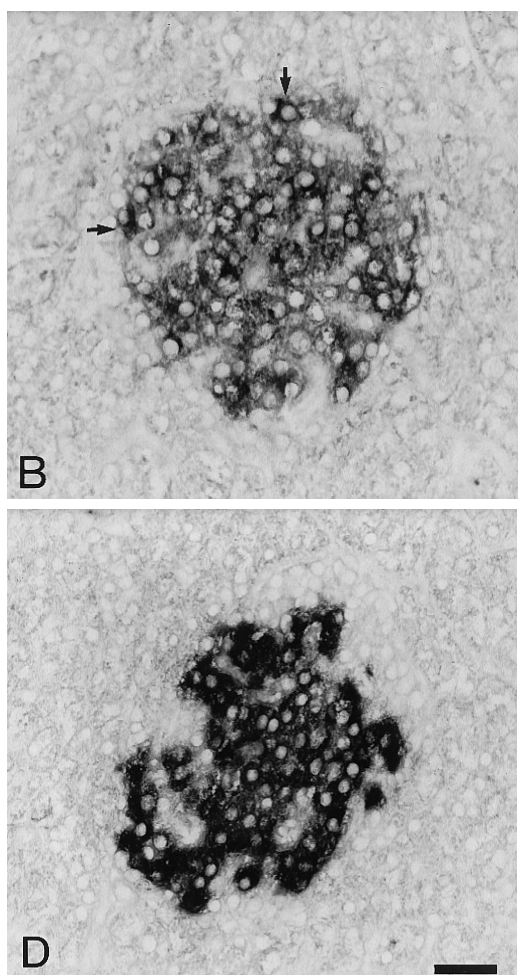

\section{Results}

Specificity of GAD65 and GAD67 monoclonal antibodies. There was no cross-reactivity between the GAD65 and GAD67 mAbs to in vitro transcribed and translated GAD67 and GAD65, respectively in immunoprecipitation analysis (data not shown). The specificities of the mAbs were further analysed in a competitive radioligand assay. In vitro transcribed and translated human GAD65 and GAD67 [15] were incubated with the mAbs raised against GAD65 andGAD67 respectively, in competition with homogenates of mocktransfected baby hamster kidney (BHK)-cells, of BHK-cells stably transfected with GAD65 and GAD67, or with rat brain homogenate which contained both GAD65 and GAD67. The binding of the GAD65 mAb to GAD65 was inhibited only by the homogenate from BHK-cells expressing GAD65 and with the brain homogenate. Similarly, the binding of the GAD67 mAb to GAD67 was only inhibited by the homogenate from BHK-cells expressing GAD67 and with the brain homogenate (not shown).

Effects of GVG and glucose on GAD in rat, pancreatic islets in vitro. Pancreatic islets were isolated from normal Wistar rats and cultured for $24 \mathrm{~h}$ in a medium containing either $5 \mathrm{mmol} / \mathrm{l}$ or $20 \mathrm{mmol} / \mathrm{l}$ glucose and either zero or $1 \mathrm{mg} / \mathrm{ml}$ of $\mathrm{GVG}$. "Soluble-protein fractions" were obtained from these cells and analyzed for GAD activity and GAD65 and GAD67 protein levels (Table 1). Compared to islets cultured only in $5 \mathrm{mmol} / \mathrm{l}$ glucose, GVG treatment did not lead to any significant changes in GAD activity or expres- 
Table 1. Effects of GVG and glucose on GAD in rat islets in vitro

\begin{tabular}{lcc}
\hline a & $5 \mathrm{mmol} / \mathrm{lglucose}$ & $20 \mathrm{mmol} / \mathrm{lglucose}$ \\
& GVG $1 \mathrm{mg} / \mathrm{ml}$ & GVG, $1 \mathrm{mg} / \mathrm{ml}$ \\
GAD activity & $59 \pm 11$ & $67 \pm 4.2^{\mathrm{a}}$ \\
GAD65 protein & $32 \pm 14$ & $20 \pm 8.6$ \\
GAD67 protein & $62 \pm 18$ & $54 \pm 8.8^{\mathrm{b}}$ \\
b & $20 \mathrm{mmol} / \mathrm{l}$ glucose & $20 \mathrm{mmol} / \mathrm{lglucose}$ \\
& no GVG & $\mathrm{GVG}, 1 \mathrm{mg} / \mathrm{ml}$ \\
GAD activity & $42 \pm 11$ & $69 \pm 29$ \\
GAD65 protein & $46 \pm 13$ & $86 \pm 35$ \\
GAD67 protein & $110 \pm 22^{\mathrm{a}}$ & $230 \pm 170$
\end{tabular}

a: Effects of GVG on GAD in islets cultured in $5 \mathrm{mmol} / \mathrm{l}$ or $20 \mathrm{mmol} / \mathrm{l}$ glucose. The results are expressed as the mean \% decrease in GAD, relative to the corresponding data obtained from islets incubated with $5 \mathrm{mmol} / \mathrm{l}$ and $20 \mathrm{mmol} / \mathrm{l}$ glucose, respectively but without GVG.

b: Effects of $20 \mathrm{mmol} / \mathrm{l}$ glucose on GAD in islets cultured with or without GVG. The effects are expressed as the mean \% increase in GAD, relative to islets incubated in $5 \mathrm{mmol} / \mathrm{lglucose}$ with no GVG or with $1 \mathrm{mg} / \mathrm{ml} \mathrm{GVG}$.

Data are from three separate experiments \pm SEM.

Each condition was performed with three separate batches of islets using 1600-1900 islets per condition. The soluble protein levels were similar between 5 and $20 \mathrm{mmol} / \mathrm{l}$ glucose, 3.2 and $3.1 \mu \mathrm{g} /$ islet respectively. The enzyme activity at 5 and $20 \mathrm{mmol} / \mathrm{l}$ glucose was 20 and $28 \mu \mathrm{U} /$ islet.

A paired, two-tailed $t$-test of the raw data was used to test for statistical significance of differences: ${ }^{\mathrm{a}} p<0.05 ;{ }^{\mathrm{b}} p<0.005$

sion. In contrast, the addition of GVG to islets cultured in $20-\mathrm{mmol} / \mathrm{l}$ glucose caused a $67 \%$ decrease in GAD activity $(p<0.05)$, and a $54 \%$ decrease in GAD67 levels $(p<0.005)$ compared to islets cultured only in $20 \mathrm{mmol} / \mathrm{l}$ glucose.

Compared to islets cultured in $5 \mathrm{mmol} / \mathrm{l}$ glucose medium without GVG, islets incubated in $20 \mathrm{mmol} / 1$ glucose medium without GVG resulted in a small, non-significant increase in GAD activity and GAD65 levels but in a marked increase in GAD67 levels $(p<0.05)$. Similarly, culturing islets in $20 \mathrm{mmol} / \mathrm{l}$ glucose medium with GVG increased GAD activity by $69 \%$, GAD65 by $86 \%$ and GAD67 by $230 \%$ compared to islets cultured in $5 \mathrm{mmol} / \mathrm{l}$ glucose in the presence of GVG, however, neither of these changes reached statistical significance due to large errors.

Effects of $G V G$ on $G A D$ in rat, pancreatic islets in vivo. To analyse the effects of in vivo GVG treatment on the islets of Langerhans, rats were injected with GVG and the pancreata analysed by immunocytochemistry using specific mAbs to GAD65 and GAD67. GAD staining could be observed in islets only. The staining reactions to both the GAD67 and GAD65 mAbs were intense in saline-treated rats (Fig. 1 A and C), but reduced after GVG-treatment, particularly for GAD67 (Fig. 1 B and D). By quantitative image processing, GVG treatment was shown to lead to a decrease in GAD67-staining intensity in islet cells to $75 \%$ of control levels $(p<0.005)$, in con-
Table 2. Effects of in vivo GVG treatment on GAD activity and GAD protein levels in rat islets and cerebrum

\begin{tabular}{llrr}
\hline & $\begin{array}{l}\text { GAD } \\
\text { activity }\end{array}$ & $\begin{array}{l}\text { GAD65 } \\
\text { levels }\end{array}$ & \multicolumn{1}{c}{$\begin{array}{c}\text { GAD67 } \\
\text { levels }\end{array}$} \\
\hline Islets & ND & $100 \pm 7.4$ & $100 \pm 2.1$ \\
Saline & ND & $87 \pm 9.8$ & $75 \pm 4.7^{\mathrm{b}}$ \\
GVG & & & \\
Cerebrum (total protein) & ND & $100 \pm 22$ & $100 \pm 13$ \\
Saline & ND & $77 \pm 17$ & $52 \pm 10^{\mathrm{a}}$ \\
GVG & & & \\
Cerebrum (soluble protein) & $100 \pm 9.0$ & $100 \pm 22$ & $100 \pm 17$ \\
Saline & $46 \pm 11^{\mathrm{b}}$ & $52 \pm 12^{\mathrm{a}}$ & $41 \pm 14^{\mathrm{a}}$ \\
GVG &
\end{tabular}

Values are expressed as a percentage of saline treated controls. In the case of the rat islets, the values are the mean optical densities \pm SEM from sections of the four animals within each test group. In the case of rat cerebrum, values are the means \pm SEM of four animals and the errors were obtained by the error propagation method which takes the SEM of both the nominator and denominator into account. ${ }^{\mathrm{a}} p<0.05 ;{ }^{\mathrm{b}} p<0.005$ (two-tailed $t$-test). ND: not done

trast, GAD65-staining intensity decreased by only $13 \%$ (NS) (Table 2).

Effects of $G V G$ on $G A D$ in rat brain in vivo. Immunoblotting analysis of the cerebral "total-protein fractions" from GVG-treated rats showed a significant decrease in GAD67 levels $(p<0.05$; Table 2$)$ compared to control preparations. GAD65 levels were not significantly changed.

Immunoblotting analysis of the cerebral "solubleprotein fractions" from GVG-treated rats also demonstrated a significant decrease in GAD67 soluble protein levels $(p<0.05$; Table 2$)$ but in addition a significant decrease in GAD65 protein levels $(p<0.05)$ was also observed. Furthermore, total GAD activity was decreased by $50 \%$ by GVG treatment $(p<0.005)$.

In the cerebella of the same animals, GAD67 was decreased by $52 \%(p<0.01)$ in "soluble-protein fractions" after treatment with GVG, whereas GAD65 levels were not significantly changed.

\section{Discussion}

The major findings of the present study are that: 1) GVG has similar effects on GAD activity and protein levels in rat islets and in rat brain. 2) Glucose enhances the expression of GAD in cultured rat islets both in the presence and absence of GVG; however, GVG and glucose appear to exert their effects on GAD expression through different mechanisms. 3) GVG appears to have different effects on membrane-associated GAD65 and soluble GAD65/ GAD67 in brain.

GVG treatment of rat pancreatic islets in $20 \mathrm{mmol} / 1$ glucose in vitro leads to decreased GAD 
activity and GAD67 levels in the "soluble-protein fractions". Results from immunocytochemical staining of pancreatic sections from rats treated with GVG in vivo demonstrate a significant decrease in GAD67 expression in islet cells, thus supporting the observations made in vitro.

In rat brain, in vivo GVG administration led to decreased GAD activity and GAD67 levels in "totalprotein fractions" (Table 2). These results confirm previous findings using homogenates as well as synaptosomal preparations from the rat cerebral cortex $[10,18,19]$. Analysis of the "soluble-protein fractions" from rat brain demonstrated a decrease also in GAD65 levels (Table 2) in the cerebrum but not in the cerebellum.

In summary, the current study clearly demonstrates that GVG, administered in vitro as well as in vivo, has effects on GAD expression in rat islet cells that are very similar to those observed in rat brain.

The primary aim of the study was to determine whether GAD expression in pancreas could be manipulated at all. The mechanism through which GVG affects GAD expression in the pancreas is not known. However, in neurons GVG's effects have been demonstrated to be secondary to its GABA-elevating effect and probably due to effects on translation and/or protein stability $[9,10,18,19]$. Previously it has been demonstrated that GVG-treatment of cultured islets leads to increased islet GABA levels [20]. GABA has also been shown to be co-localized with GAD in mouse beta cells [21] and in cultured rat islets [3] and GABA-T has been demonstrated in beta cells [22]. On the basis of these findings it seems likely that GVG exerts its effect on the GAD proteins through increased GABA levels and subsequently through effects on stability/translation of the enzyme also in beta cells.

The somewhat selective effect of GVG on GAD67 protein expression could be because most of the shortterm regulation of GAD65 enzymatic activity is mediated through its interaction with the co-factor pyridoxal 5'-phosphate, since a significant portion of GAD65 exists as an apo-enzyme, i. e. not bound to pyridoxal 5'-phosphate. In contrast GAD67 mainly exists as a holo-enzyme, i.e. bound to pyridoxal 5' phosphate, and thus probably mainly regulated via translation and/or protein stability as discussed above.

The observation that GAD65 levels were also decreased when "soluble-protein fractions" from the cerebra of GVG-treated rats were assayed was unexpected, but may be explained by the differences in the membrane-anchoring capability of GAD67 and GAD65. Thus, GAD65 is associated with membranes both in nerve cells [23] and in beta cells [1, 24-26]. In nerve cells, GAD67 is mainly present in the perikarya (soluble) while there is relatively more GAD65 than GAD67 in the nerve terminals (membrane-associated) $[1,18,27-29]$. In the beta cell, as little as $6 \%$ of GAD65 is estimated to be soluble [30, 31]. Membrane-anchoring may somehow make GAD65 "inaccessible" to the actions of GVG, so decreases in GAD67 would be the main observation in "total-protein fractions".

Incubation of rat islets in $20 \mathrm{mmol} / \mathrm{l}$ glucose medium increased the levels of GAD proteins and GAD activity (Table 2). However, although these results were not statistically significant, they agree well with studies from other laboratories. For example, Hao et al. [32] demonstrated an approximately $50 \%$ increase in GAD65 levels and 100\% increase in GAD67 levels in rat islets cultured in $5 \mathrm{compared}$ to $20 \mathrm{mmol} / \mathrm{l}$ glucose and Velloso et al. [33] could show significant increases in GAD mRNA expression in rat islets when cultured in $11 \mathrm{mmol} / 1$ glucose.

The high-glucose-induced increase in GAD activity and levels observed in the present study could also be observed in cultured islets treated with GVG. This observation together with the fact that GVG actually decreased GAD expression in islets cultured both under high- and normal-glucose conditions (Table 1), suggests that glucose and GVG act on GAD through different mechanisms. As discussed above, there is good evidence that GVG's decreasing effects on GAD expression in brain as well as in islet cells are secondary to increases in GABA levels and probably due to effects on translation and/or protein stability [18]. By contrast, it has been demonstrated that high-glucose treatment of rat islets in vitro leads to increases in GAD mRNA levels [33].

The results from this study show that the expression of GAD65 and GAD67 are regulated similarly in rat islet cells and in rat neurons. The fact that even very low doses of GVG have been demonstrated to have substantial effects on neuronal GAD67 expression [18] gives strong support to the idea that this type of regulation has physiologically and maybe, in the case of IDDM and stiff-man syndrome, pathophysiological relevance. There are indications that by downregulating beta-cell function ("beta-cell rest"), e.g., by diazoxide treatment [34] or by insulin s.c./i.v. [35] the autoimmune beta-cell destruction may be halted or stopped. This effect has been suggested in part to be mediated by a reduced expression of betacell autoantigens, supported by the finding that metabolic stress on beta cells, e. g. by high glucose concentrations results in the upregulation of autoantigens, e.g. GAD65, insulin [32, 33], which consequently could lead to increased immune recognition of the beta cells. We have therefore initiated studies to investigate whether GVG, which we here have shown modulate the expression of GAD in beta cells, can be used to deviate or inhibit islet cell autoimmunity.

Acknowledgements. The authors wish to thank Anne Mette Gjedsted, Steen Kryger and Else Jost Jensen for expert technical assistance. 


\section{References}

1. Erlander MG, Tillakaratne NJK, Feldblum S, Patel N, Tobin AJ (1991) Two genes encode distinct glutamate decarboxylases. Neuron 7: 91-100

2. Martin DL, Rimvall K (1993) Regulation of g-aminobutyric acid synthesis in the brain. J Neurochem 60: 395-407

3. Petersen JS, Russel S, Marshall MO et al. (1993) Differential expression of glutamic acid decarboxylase in rat and human islets. Diabetes 42: 484-495

4. Cram DS, Faulkner-Jones B, Kun J, Harrison LC (1995) Glutamic acid decarboxylase-67 (GAD67): Expression relative to GAD65 in human islets and mapping of autoantibody epitopes. Endocrinology 136: 1111-1119

5. Bækkeskov S, Aanstoot H-J, Christgau S et al. (1990) Identification of the $64 \mathrm{~K}$ autoantigen in insulin-dependent diabetes as the GABA-synthesizing enzyme glutamic acid decarboxylase. Nature 347: 151-156

6. Clare-Salzler MJ, Tobin AJ, Kaufman DL (1992) Glutamate decarboxylase: An autoantigen in IDDM. Diabetes Care 15: 132-143

7. Bækkeskov S, Landin M, Kristensen JK et al. (1987) Antibodies to a $64,000 \mathrm{M}_{\mathrm{R}}$ human islet cell antigen precede the clinical onset of insulin-dependent diabetes. J Clin Invest 79: 926-934

8. Worsaae A, Hejnaes K, Moody A et al. (1995) T-cell proliferative responses to glutamic acid decarboxylase-65 in IDDM are negatively associated with HLA-DR3/4. Autoimmunity 22: 183-189

9. Rimvall K, Martin DL (1992) Increased intracellular gaminobutyric acid selectively lowers the level of the larger of two glutamate decarboxylase proteins in cultured GABAergic neurons from rat cerebral cortex. J Neurochem 58: 158-166

10. Rimvall K, Martin DL (1994) The level of $\mathrm{GAD}_{67}$ protein is highly sensitive to small increases in intraneuronal g-aminobutyric acid levels. J Neurochem 62: 1375-1381

11. Vermeij FH, van Doorn PA, Busch HFM (1996) Improvement of stiff-man syndrome with vigabatrin. Lancet 348: 612

12. Petersen JS, Karlsen AE, Markholst H, Worsaae A, Dyrberg T, Michelsen B (1994) Neonatal tolerization with glutamic acid decarboxylase but not with bovine serum albumin delays the onset of diabetes in NOD mice. Diabetes 43: $1478-1484$

13. Taggart RT, Samloff IM (1983) Stable antibody producing murine hybridomas. Science 219: 1228-1231

14. Moody A, Hejnæs KR, Marshall MO et al. (1995) The isolation by anion-exchange of immunologically and enzymatically active human islet glutamic acid decarboxylase 65 overexpressed in Sf9 insect cells. Diabetologia 38: 14-23

15. Petersen JS, Hejnæs KR, Moody A et al. (1994) Detection of $\mathrm{GAD}_{65}$ antibodies in diabetes and other autoimmune diseases using a simple radioligand assay. Diabetes 43: 459-467

16. Gotfredsen CG, Stewart MG, O'Shea GM, Vose JR, Horn T, Moody AJ (1990) The fate of transplanted encapsulated islets in spontaneously diabetic BB/Wor rats. Diabetes Res Clin Pract 15: 157-163

17. Denner LA, Wu J-Y (1985) Two forms of rat brain glutamic acid decarboxylase differ in their dependence on free pyridoxal phosphate. J Neurochem 44: 957-965

18. Rimvall K, Sheikh SN, Martin DL (1993) Effects of increased g-aminobutyric acid levels on $\mathrm{GAD}_{67}$ protein and mRNA levels in rat cerebral cortex. J Neurochem 60: 714-720

19. Sheikh SN, Barke K, Waniewski RA, Martin DL (1994) Increased GABA levels selectively reduce $\mathrm{GAD}_{67}$ protein in various regions of rat brain. Soc Neurosci Abstr 24: 916 (Abstract)

20. Taniguchi H, Okada Y, Kobayashi T, Murakami K, Baba S (1978) High concentration of g-aminobutyric acid and its role in beta-cells of pancreatic islets. In: Baba S, Kaneko T, Yanaihara N (eds) Proinsulin, insulin, C-peptide. Excerpta Medica. Amsterdam, Oxford, pp 334-347

21. Gilon P, Bertrand G, Loubatieres-Mariani MM, Remacle C, Henquin JC (1991) The influence of g-aminobutyric acid on hormone release by the mouse and rat endocrine pancreas. Endocrinology 129: 2521-2529

22. Sorenson RL, Garry DG, Brelje TC (1991) Structural and functional considerations of GABA in islets of Langerhans. Beta-cells and nerves. Diabetes 40: 1365-1374

23. Reetz A, Solimena M, Matteoli M, Folli F, Takei K, De Camilli P (1991) GABA and pancreatic beta-cells: colocalization of glutamic acid decarboxylase (GAD) and GABA with synaptic-like microvesicles suggests their role in GABA storage and secretion. EMBO J 10: 1275-1284

24. Shi Y, Veit B, Bækkeskov S (1994) Amino acid residues 24-31 but not palmitoylation of cysteines 30 and 45 are required for membrane anchoring of glutamic acid decarboxylase, GAD 65 . J Cell Biol 124: 927-934

25. Solimena M, Aggujaro D, Muntzel C et al. (1993) Association of GAD-65, but not of GAD-67, with the Golgi complex of transfected Chinese Hamster Ovary cells mediated by the N-terminal region. Proc Natl Acad Sci USA 90: 3073-3077

26. Thomas-Reetz AC, De Camilli P (1994) A role for synaptic vesicles in non-neuronal cells: clues from pancreatic b cells and from chromaffin cells. FASEB J 8: 209-216

27. Kaufman DL, Houser CR, Tobin AJ (1991) Two forms of the gamma-aminobutyric acid synthetic enzyme glutamate decarboxylase have distinct intraneuronal distributions and cofactor interactions. J Neurochem 56: 720-723

28. Gonzales C, Kaufman DL, Tobin AJ, Chesselet M-F (1991) Distribution of glutamic acid decarboxylase $\left(M_{r} 67000\right)$ in the basal ganglia of the rat: an immunohistochemical study with a selective cDNA-generated polyclonal antibody. J Neurocytol 20: 953-961

29. Henry S, Tappaz M (1991) Relative enrichment of the lighter $59 \mathrm{kDa}$ form of glutamic acid decarboxylase in nerve endings: an immunoblotting study in pituitary neurointermediate lobe. Neurosci Lett 131: 253-256

30. Christgau S, Schierbeck H, Aanstoot H-J et al. (1991) Pancreatic b cells express two autoantigenic forms of glutamic acid decarboxylase, a 65-kDa hydrophilic form and a 64$\mathrm{kDa}$ amphiphilic form which can be both membrane-bound and soluble. J Biol Chem 266: 21257-21264

31. Christgau S, Aanstoot H-J, Schierbeck H et al. (1992) Membrane anchoring of the autoantigen $\mathrm{GAD}_{65}$ to microvesicles in pancreatic beta-cells by palmitoylation in the $\mathrm{NH}_{2}$-terminal domain. J Cell Biol 118: 309-320

32. Hao W, Li L, Mehta V, Lermark Å, Palmer JP (1994) Functional state of the $b$ cell affects expression of both forms of glutamic acid decarboxylase. Pancreas 9: 558-562

33. Velloso LA, Björk E, Ballagi AE et al. (1994) Regulation of GAD expression in islets of Langerhans occurs both at the mRNA and protein level. Mol Cell Endocrinol 102: 31-37

34. Bjork E, Berne C, Kampe O, Wibell L, Oskarsson P, Karlsson FA (1996) Diazoxide treatment at onset preserves residual insulin-secretion in adults with autoimmune diabetes. Diabetes 45: 1427-1430

35. Keller RJ, Eisenbarth GS, Jackson RA (1993) Insulin prophylaxis in individuals at high-risk of type-1 diabetes. Lancet 341: 927-928 